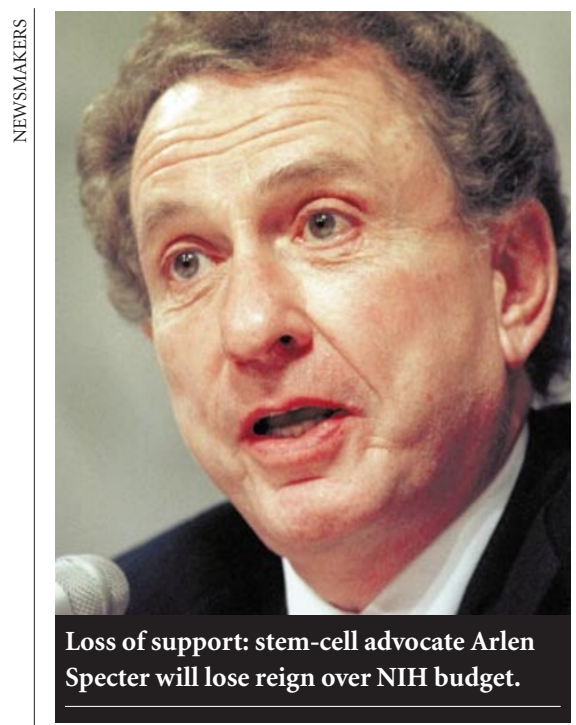

- confrontational stance with the new administration, so as not to drive Bush into appeasing the opponents of embryo research.

The current NIH regime is still setting up a stem-cell research programme. This effort is rooted in a legal opinion, crafted under President Bill Clinton's administration, that says the US government can fund research with stem cells derived from human embryos, despite the agency being prohibited by law from supporting work with the embryos themselves. This opinion - which even some researchers think is shaky - would take little executive action to reverse.

Advocates of stem-cell research are worried that Bush could overturn the ruling without having to cut off funding for any research already underway. Rather, the administration could avoid the political heat that would come from ending the programme outright by requesting additional reviews that would, in effect, delay funding indefinitely.

Even if the current policy remained intact, NIH officials do not anticipate approving any embryonic stem-cell research until May at the earliest. The deadline for the first round of applications is 15 March.

People familiar with the process say that a key hold-up is the lack of embryonic stem-cell lines that comply with NIH guidelines. The NIH is also still vetting members of its new Human Pluripotent Stem Cell Review Group, which will review all funding requests.

Meanwhile, the expected departure of Senator Arlen Specter (Republican, Pennsylvania), the most active supporter of stem-cell research in the US Congress, from the chairmanship of the appropriations panel overseeing the NIH budget, could further weaken the chances of obtaining federal funds.

\section{New regime may aim to craft compromise on green issues}

Tony Reichhardt, Washington

Environmental scientists are waiting for signs of the new US administration's attitude towards basic environmental research. Areas such as global warming, air particulates, genetically modified food and endangered species have all been political battlegrounds in the past.

Although he strongly opposes the Kyoto climate treaty, during the presidential campaign George W. Bush came out in favour of research into the causes and impact of global warming. Otherwise, neither candidate mentioned the environment much.

As president, Bush's top environmental priority will be to devolve federal pollution controls. He views these as a matter for individual states and industry, rather than the government in Washington, to determine. approach alarms the environmental lobby, which recalls attempts by President Ronald Reagan's administration to roll back federal environmental regulation in the 1980s. Environmentalists hope that Bush will not be as heavy-handed as Reagan, who hired controversial figures such as Interior Secretary James Watt to dismantle programmes seen as unfriendly to corporations or land developers.

So far, Bush has taken advice from a dozen or so conservative policy experts and state office-holders. Many of these are skilled at crafting compromises between environmenly to fill key jobs in the new administration.

Led by Christopher DeMuth, head of the American Enterprise Institute, a conservative think-tank, they began advising Bush in mid-1999 on issues ranging from land use to global warming. This informal group of laissez-faire environmentalists includes Gayle Norton, former attorney general of Colorado; Lynn Scarlett of the Los Angelesbased Reason Public Policy Institute; Robert Nelson of the Competitive Enterprise Insti-
Bush's preference for the local, voluntary talists and business, and some of them are like- tute; Montana Governor Marc Racicot; and Richard Schmalensee, dean of the Sloan School of Management at the Massachusetts Institute of Technology, who has advised Bush on the economics of climate treaties.

One member of the group touted as a possible adminstrator of the Environmental Protection Agency (EPA) is Mary Gade, who spent 13 years working for the agency and is currently head of Illinois' environmental agency. Bush is also said to be considering two other heads of state environmental agencies, James Seif of Pennsylvania and David Struhs of Florida, for the post.

Racicot has long been seen as a potential secretary at the Department of the Interior, which administers the Endangered Species Act and includes the US Geological Survey. Another contender is Slade Gorton, who has just lost his Senate seat in the state of Washington, and who used to chair the Senate subcommittee overseeing the department's budget.

Such appointments will point the way for Bush's environmental policy, says Peter Saundry, executive director of the National Council for Science and the Environment, which lobbies for environmental research. Unlike Al Gore, who as vice-president was deeply involved in environmental policy, Bush will be inclined to delegate, Saundry says. This will give agency heads and their subordinates more leeway to shape policy.

Funding for research at the EPA, and at the interior and agriculture departments will be another key measure of the administration's commitment to environmental protection. The brightest prospects for environmental science may be at the National Science Foundation, which has been planning a that, given past Republican calls for sound science to underpin environmental policy, this expansion will proceed under the new administration. dramatic expansion of its environmental research programme. Saundry is hopeful

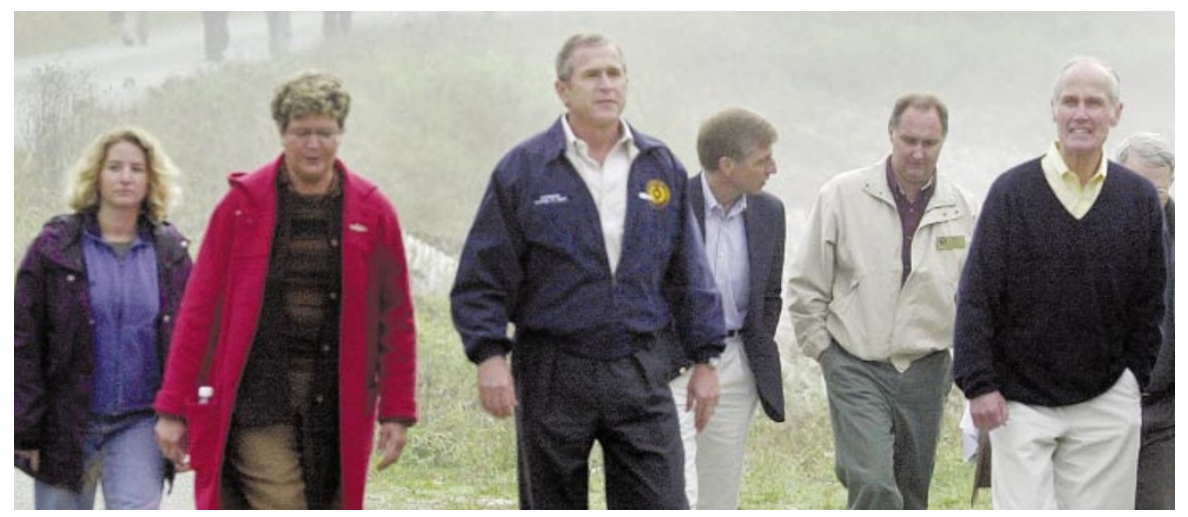

On a green path? Bush discusses environmental policies with landowners in Washington state. 